\title{
ANALISIS ISU KEBIJAKAN DALAM PENGEMBANGAN KELEMBAGAAN PEMERINTAHAN (STUDI PADA KELEMBAGAAN PENYULUH DI KABUPATEN PESAWARAN)
}

\author{
Maulana Mukhlis \\ Jurusan Ilmu Pemerintahan FISIP Universitas Lampung \\ Email: maulanamukhlis1978@gmail.com
}

\begin{abstract}
In carrying out government functions, local governments are still faced with limited resources, both institutional and personnel. This paper will answer questions about what public policy issues are developing in government institutions (in this case, the extension agency in Pesawaran District) as well as what alternative policy recommendations should be done to address various policy issues in the future. The choice of government institutions in the agricultural sector (including fisheries and forestry) which is supported by two main arguments is not only one of the obligatory functions of the regional government, but also because this sector has proven to be reliable in facing the economic crisis because of the basic livelihoods of the inhabitants of Pesawaran District. Policy research was chosen as the type of research using the interview method and documentation study to obtain primary and secondary data. The results showed that the strategic issues of the institutions in Pesawaran District in general consisted of seven aspects, namely the institutional aspects of extension workers and farmer groups, the quality aspects of the extension workers, the aspects of farmers, the aspects of cooperation, the aspects of infrastructure, the aspects of the implementation of extension, and the aspects of financing. The directives focus mainly on institutional extension workers with the main program for institutional improvement which is compiled on the basis of three references (sources), namely normative sources, regulatory sources, and participatory sources. Keywords: Policy Issues, Government Institutions, Development Extension Officers
\end{abstract}

\begin{abstract}
ABSTRAK
Dalam menjalankan fungsi pemerintahan, pemerintah daerah masih dihadapkan pada keterbatasan sumber daya, baik kelembagaan maupun personil. Paper ini akan menjawab pertanyaan tentang isu-isu kebijakan publik apa yang berkembang pada kelembagaan pemerintah (dalam hal ini adalah kelembagaan penyuluh di Kabupaten Pesawaran) serta alternatif rekomendasi kebijakan seperti apa yang harus dilakukan untuk mengatasi berbagai isu kebijakan di masa depan. Pilihan pada kelembagaan pemerintah sektor pertanian (termasuk perikanan dan kehutanan) didukung oleh dua argumentasi utama yakni selain merupakan salah satu urusan wajib pemerintah daerah, juga karena sektor ini terbukti dapat diandalkan dalam menghadapi krisis ekonomi karena menyangkut pencaharian pokok mayoritas pendududuk Kabupaten Pesawaran. Penelitian kebijakan dipilih sebagai tipe penelitian dengan menggunakan metode wawancara dan studi dokumentasi untuk mendapatkan data primer dan sekunder. Hasil penelitian menunjukkan bahwa isu strategis yang dihadapi oleh kelembagaan penyuluh di Kabupaten Pesawaran secara umum terdiri atas tujuh aspek, yakni aspek kelembagaan penyuluh dan kelompok tani, aspek kualitas penyuluh,
\end{abstract}


aspek petani, aspek kerja sama, aspek sarana prasarana, aspek penyelenggaraan penyuluhan, dan aspek pembiayaan. Arahan rekomendasi difokuskan terutama pada aspek kelembagaan penyuluh dengan program utama peningkatan kapasitas kelembagaan yang disusun atas dasar tiga acuan (sumber) yaitu sumber normatif, sumber regulatif, dan sumber partisipatif.

Kata Kunci : Isu Kebijakan, Kelembagaan Pemerintah, Penyuluh.

\section{PENDAHULUAN}

Undang-Undang Nomor 23 Tahun 2014 tentang Pemerintahan Daerah disusun sebagai bagian dari upaya mewujudkan tujuan utama otonomi daerah yaitu mempercepat terwujudnya kesejahteraan masyarakat melalui peningkatan pelayanan, pemberdayaan dan partisipasi masyarakat serta peningkatan daya saing daerah secara efektif dan efisien. Terdapat beberapa aspek yang perlu diperhatikan dalam upaya mewujudkan efisiensi dan efektivitas penyelenggaraan pemerintahan di daerah, beberapa diantaranya adalah aspek hubungan antar susunan pemerintahan dan antar pemerintahan daerah, aspek potensi dan keanekaragaman daerah, serta aspek peluang dan tantangan persaingan secara global. Salah satu permasalahan yang dihadapi oleh hampir semua pemerintah daerah di Indonesia dalam pelaksanaan desentralisasi adalah masalah birokrasi dan kualitas kelembagaan daerah (Wicaksono, 2012). Birokrasi pemerintahan daerah dan kualitas kelembagaan daerah seyogyanya harus dikuatkan kemampuannya sehingga mampu menjalankan sistem otonomi yang diberikan secara maksimal dalam rangka menjalankan kewenangan, tugas pokok, serta urusan pemerintahan daerah yang menjadi urusan pemerintah daerah.

Pengembangan

kapasitas

kelembagaan atau organisasi merupakan salah satu fokus dalam studi pengembangan kelembagaan sektor publik. Pengembangan kapasitas diartikan sebagai peningkatan kemampuan atau kompetensi individu, kelompok dan organisasi yang mencakup banyak komponen, sehingga dalam pengembangan kapasitas terdapat beberapa dimensi dan fokus. Dimensi dan fokus tersebut merupakan bagian proses dinamis yang berkelanjutan. Menurut Soeprapto (2003) terdapat tiga tingkatan dimensi atau fokus pengembangan kapasitas, yaitu:

1. Tingkatan individual, misalnya potensi-potensi individu, keterampilan individu, kategorisasi pekerjaan serta motivasi individu yang mendorong kualitas pekerjaan dalam sebuah organisasi.

2. Tingkatan organisasi, seperti struktur organisasi, prosedur dan mekanisme pekerjaan, prosesd pengambilan keputusan didalam organisasi, pemanfaatan sarana prasarana serta infrastruktur, pola hubungan serta jaringan organisasi dalam kaitannya dengan organisasi eksternal.

3. Tingkatan sistem, seperti kerangka kerja yang berhungan dengan regulasi, program dan kondisi awal yang mendukung pencapaian tujuan suatu kebijakan.

Kabupaten Pesawaran Provinsi Lampung, sebagai daerah otonom yang baru berdiri pada tanggal 17 Juli 2007 memiliki potensi pertanian, perikanan dan kehutanan yang sangat besar. Menyadari besarnya potensi tersebut, maka pada Pemerintah Kabupaten Pesawaran telah membentuk organisasi perangkat daerah yang dibentuk berdasarkan Peraturan Daerah Kabupaten Pesawaran Nomor 6 Tahun 2016 tentang Pembentukan dan Susunan Perangkat Daerah. Salah satunya adalah 
Badan Pelaksana Penyuluhan Pertanian, Perikanan dan Kehutanan (BP4K) sebagai bagian dari Organisasi Perangkat Daerah yang merupakan unsur pelayanan tugas pemerintah bidang penyuluhan. Pada tingkat kecamatan juga telah terbentuk Balai Penyuluhan Pertanian, Perikanan, dan Kehutanan (BP3K) Kecamatan. Penguatan kelembagaan pada sektor pertanian sangat argumentatif dilakukan karena mayoritas penduduk pedesaan bermata pencaharian sebagai petani (Vintarno, 2019).

Namun demikian keberadaan dan kinerja BP4K di tingkat kabupaten maupun BP3K di tingkat kecamatan sampai saat ini dirasakan belum maksimal. Hal tersebut ditunjukkan dengan belum optimalnya kapasitas kelembagaan penyuluhan, masih rendahnya dukungan pemerintah (pusat, provinsi, maupun pemerintah daerah kabupaten sendiri) dalam pemenuhan sarana dan prasarana serta pembiayaan pengelololaan kelembagaan penyuluh dan penyelenggaraan penyuluhan. Selain itu, juga maish minimnya kepedulian pimpinan daerah dan stakeholders lain tentang keberadaan BP4K maupun BP3K sehingga pelayanan kepada masyarakat petani di Kabupaten Pesawaran belum optimal (Renstra BP4K Kabupaten Pesawaran, 2015-2020).

Fakta-fakta di atas menunjukkan bahwa pengembangan kapasitas pemerintah daerah sama artinya dengan upaya meningkatkan kinerja pelayanan kepada masyarakat pada urusan-urusan tertentu. Oleh karena itu, penting bagi pemerintah daerah untuk melaksanakan capacity building dengan tujuan memperbaiki dan memperbarui sistem yang telah ada supaya dapat lebih maksimal dari kondisi sebelumnya. Berdasarkan Peraturan Pemerintah No. 59 Tahun 2012 Tentang Kerangka
Nasional Pengembangan Kapasitas Pemerintahan Daerah, BP4K Kabupaten Pesawaran sebagai institusi pemerintahan di daerah idealnya juga harus melaksanakan pengembangan kapasitas kelembagaan dalam rangka menjalakan salah satu urusan wajib daerah dalam bidang pertanian sebagai pencaharian mayoritas penduduk perdesaan.

Menurut laporan Kementerian Pertanian (2015) kegiatan penyuluhan pertanian di Indonesia (terutama di daerah) mengalami dua persoalan utama, yaitu (a) kelembagaan penyuluhan pertanian sering berubahubah, sehingga kegiatannya sering mengalami masa transisi. Kondisi ini menyebabkan penyuluhan pertanian di lapangan sering terkatung-katung dan kurang berfungsi. Semangat kerja para Penyuluh Pertanian Lapangan (PPL) yang status kepegawaiannya tidak pasti, juga menurun. (b) jumlah PPL yang ada kurang mencukupi dibanding dengan kebutuhan, demikian pula kualitas dan kapasitasnya. Umumnya pendidikan mereka hanya setingkat SLTA sehingga kurang mampu mendukung petani dalam menghadapi persoalan pertanian yang semakin kompleks. Untuk mengatasi persoalan ini, pemerintah telah meningkatkan kemampuan mereka melalui berbagai pelatihan, namun frekuensi kegiatan semacam ini cenderung masih kurang memadai sehingga upaya peningkatan kapasitas penyuluh penting dilakukan (Sunartomo, 2016).

Oleh karena itu, sangat penting meyakinkan adanya eksistensi suatu kelembagaan penyuluhan pertanian yang dapat menfasilitasi sistem penyuluhan pertanian agar petani dan pelaku usaha lainnya dapat bekerjasama secara produktif dengan fasilitasi dan pendampingan edukatif oleh penyuluh (Wahyuni, dkk, 2019). Kelembagaan ini 
berfungsi sebagai home base dan unit yang melakukan pembinaan karier penyuluh pertanian, serta unit manajemen yang menjamin berlangsungnya proses penyuluhan pertanian terpadu yang efisien, efektif, produktif dan bersifat sinergi dengan program pengembangan komoditas pertanian sesuai potensi daerah, khususnya di daerah otonom baru Kabupaten Pesawaran.

Argumen dasar dalam paper ini adalah bahwa untuk bisa mengatasi berbagai masalah-masalah dalam pelayanan publik dibutuhkan kelembagaan pemerintah yang memiliki kapasitas sehingga mampu secara optimal menyelenggarakan fungsifungsi pemerintahan. Untuk mengetahui masalah tersebut, dapat dilakukan dengan mengidentifikasi isu-isu kebijakan publik yang berkembang di masyarakat sebagai dasar menyusun rekomendasi kebijakan. Dewasa ini masalah kebijakan dan problem pelayanan publik berkembang sangat dinamis, bukan hanya pada aspek produksinya namun juga pada aspek diversitasnya. Dinamika ini tidak terlepas dari adanya tuntutan masyarakat yang juga semakin meningkat. Pada saat yang sama, pemerintah daerah untuk dihadapkan pada keterbatasn sumber daya yang tersedia untuk mengatasi persoalanpersoalan tersebut.

Berdasarkan identifikasi masalah tersebut, pertanyaan yang akan dijawab dalam paper ini yaitu: (1) isu-isu kebijakan publik apa yang berkembang pada kelembagaan pemerintah (dalam hal ini BP4K Kabupaten Pesawaran)? (2) keterbatasan apa yang dihadapi oleh BP4K Kabupaten Pesawaran dalam mengatasi isu-isu kebijakan publik dan pelayanan publik?, dan (3) rekomendasi kebijakan apa yang bisa ditawarkan dalam mengatasi berbagai isu kebijakan yang dialami oleh BP4K Kabupaten Pesawaran tersebut?.

\section{METODE}

Penelitian ini dilakukan dengan menggunakan jenis penelitian kebijakan (policy research). Menurut Majchrzak (1984), penelitian kebijakan adalah the process of conducting research on, or analysis of a fundamental social problem in order to provide policy makers with pragmatic, action oriented recommendation for alleviating problems (proses pelaksanaan penelitian atau analisis mengenai suatu masalah sosial mendasar guna membantu pembuat kebijakan dengan cara menyajikan rekomendasi yang bersifat pragmatis, berorientasi pada aksi untuk mengatasi masalah tersebut). Pengumpulan data dipergunakan dua cara, yaitu wawancara mendalam dengan beberapa perangkat daerah terkait (BP4K, Bappeda, dan seluruh $\mathrm{BP} 3 \mathrm{~K})$ dalam rangka memperoleh data primer. Sementara, data sekunder diperoleh dari berbagai publikasi, dokumentasi serta laporan penyelenggaraan kegiatan penyuluhan pada BP4K Kabupaten Pesawaran.

Sebagai fokus kajian, dipergunakan rujukan menurut Undang Undang No. 16 Tahun 2006 tentang Sistem Penyuluhan Pertanian, Perikanan dan Kehutanan yang menyatakan bahwa strategi penyuluhan terdiri atas minimal 5 (lima) sub sistem yaitu subsistem kelembagaan, ketenagaan, metode penyelenggaraan penyuluhan, sarana prasarana, serta subsistem pembiayaan. Masing-masing subsistem tersebut memiliki fokus kajian yang saling terkait dalam mend orong keberhasilan sistem penyuluhan pertanian secara terpadu dan komprehensif. 
Gambar 1. Posisi Peningkatan Kapasitas BP4K dalam Revitalisasi Kelembagaan Pemerintah Daerah

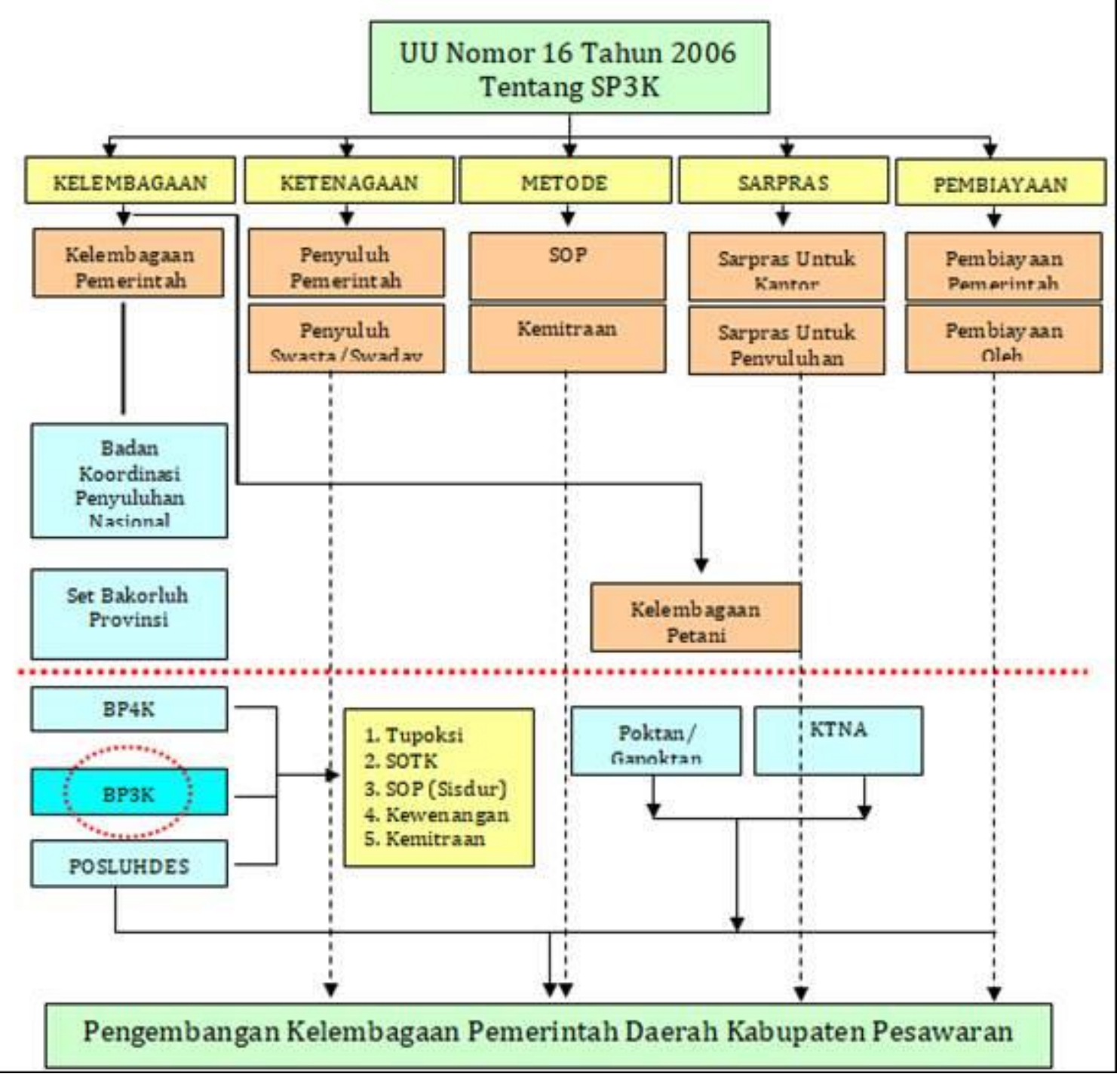

Sumber: Diolah kembali dari UU No. 16 Tahun 2006.

Dengan menggunakan konsep pengembangan kelembagaan sebagaimana bagan 1, paper ini menghasilkan berbagai deskripsi tentang persoalan keterbatasan kelembagaan pemerintah daerah dalam mengatasi berbagai problema publik (dalam hal ini lembaga BP4K Kabupaten Pesawaran), mengidentifikasi isu-isu kebijakan publik yang muncul pada BP4K Kabupaten Pesawaran, menjelaskan upaya yang dilakukan BP4K Kabupaten Pesawaran dalam memecahkan berbagai persoalan isu-isu kebijakan dan masalah pelayanan publik dalam sektor pertanian, serta memberikan rekomendasi kebijakan dalam menyelesaikan masalah-masalah yang muncul dalam dalam rangka mengantisipasi dan mengatasi berbagai isu kebijakan yang dihadapi dalam praktik penyelenggaraan pemerintahan daerah. 


\section{HASIL DAN PEMBAHASAN Isu Kebijakan dan Dinamikanya}

Dalam pelbagai literatur istilah isu itu tidak pernah dirumuskan dengan jelas, namun sebagai suatu "technical term' utamanya dalam konteks kebijakan publik, muatan maknanya lebih kurang sama dengan apa yang kerap disebut sebagai "masalah kebijakan" (policy problem). Dalam analisis kebijakan publik, konsep ini menempati posisi sentral. Hal tersebut mungkin ada kaitannya dengan fakta, bahwa proses pembuatan kebijakan publik apa pun pada umumnya berawal dari adanya awareness of a problem (kesadaran akan adanya masalah tertentu). Misalnya, gagalnya kebijakan tertentu dalam upayanya mengatasi suatu masalah pada suatu tingkat yang dianggap memuaskan. Tapi, pada situasi lain, awal dimulainya proses pembuatan kebijakan publik juga bias berlangsung karena adanya masalah tertentu yang sudah sekian lama dipersepsikan sebagai "belum pernah tersentuh" oleh atau ditanggulangi lewat kebijakan pemerintah. Pada titik ini kemudian mulai membangkitkan tingkat perhatian tertentu (Wahab, 2002).

Jadi, pada intinya isu kebijakan (policy issues) lazimnya muncul karena telah terjadi silang pendapat di antara para aktor mengenai arah tindakan yang telah atau akan ditempuh, atau pertentangan pandangan mengenai karakter permasalahan itu sendiri.

Isu kebijakan dengan begitu lazimnya merupakan produk atau fungsi dari adanya perdebatan baik tentang rumusan rincian, penjelasan, maupun penilaian atas suatu masalah tertentu (Dunn, 2000). Pada sisi lain, isu bukan hanya mengandung makna adanya masalah atau ancaman, tetapi juga peluang-peluang bagi tindakan positif tertentu dan kecenderungankecenderungan yang dipersepsikan sebagai memiliki nilai potensial yang signifikan (Hogwood dan Gunn, 1984). Dipahami seperti itu, maka isu bisa jadi merupakan kebijakan-kebijakan alternatif atau suatu proses yang dimaksudkan untuk menciptakan kebijakan baru, atau kesadaran suatu kelompok mengenai kebijakan tertentu yang dianggap bermanfaat bagi mereka. Singkatnya, timbulnya isu kebijakan publik terutama karena telah terjadi konflik atau "perbedaan persepsional" di antara para aktor atas suatu situasi problematik yang dihadapi oleh masyarakat pada suatu waktu tertentu.

Dengan pemahaman bahwa kajian peningkatan kapasitas kelembagaan pemerintah daerah (dalam hal ini BP4K Kabupaten Pesawaran) merupakan sub sistem dari revitalisasi penyuluhan secara umum, maka dalam mengkaji aspek kelembagaan tidak bisa hanya dilakukan secara tersendiri, namun juga bisa dan harus terkait dengan aspek-aspek dalam sub sistem lainnya. Oleh karena itu, dalam penentuan isu strategis (permasalahan pokok) yang dihadapi dalam pelaksanaan penyuluhan oleh BP3K di Kabupaten Pesawaran selama ini akan dibagi ke dalam 7 (tujuh) aspek pengelompokan yakni (1) aspek kelembagaan penyuluh pemerintah mulai tingkat BP4K hingga Posluhdes, (2) aspek rendahnya kualitas dan kuantitas tenaga penyuluh, (3) aspek petani dan kelembagaan di tingkat petani, (4) aspek kerja sama baik antara penyuluh dengan profesi lainnya, maupun antara OPD yang berurusan dengan sektor pertanian, perikanan dan kehutanan khususnya di Kabupaten Pesawaran (5) aspek metode penyelenggaraan penyuluhan, (6) aspek sarana dan prasarana, serta (7) aspek pembiayaan. Namun demikian, paper ini hanya akan terfokus pada aspek kelembagaan penyuluh. 


\section{Identifikasi Isu dan Masalah Kelembagaan Penyuluh}

Kegiatan penyuluhan memerlukan suatu bentuk organisasi tertentu. Hal ini, disebabkan karena kegiatan penyuluhan melibatkan banyak pihak yang terbagi dalam kelompokkelompok atau unit kerja yang memiliki fungsi masing-masing, baik penentu kebijakan penyuluhan, penyuluh, maupun para "petani maju" yang sering diminta keterlibatannya sebagai penyuluh sukarela. Selain itu, kegiatan penyuluhan memiliki tujuan bersama, yaitu mengubah perilaku masyarakat sasarannya agar dapat membantu dirinya sendiri dalam rangka memperbaiki mutu hidup dan kesejahteraan masyarakatnya.

Menurut Clear dan Bentz (1987) manfaat keberadaan organisasi penyuluhan dilatarbelakangi oleh beberapa faktor. Pertama, di dalam kegiatan penyuluhan, sebagai suatu sistem pendidikan, masyarakat dapat dengan bebas untuk menerima atau menolak informasi/inovasi yang ditawarkan kepadanya. Oleh karena itu, setiap penyuluh harus diorganisir sebaik-baiknya oleh setiap lembagalembaga pemerintah yang bersangkutan agar mereka benar-benar memahami latar belakang sosial budaya masyarakat sasarannya serta mampu dan mau menjalin hubungan yang erat dengan pusat-pusat informasi tentang teknologi pertanian, keadaan lingkungan hidup, dan pusat-pusat informasi tentang sosial budaya setempat. Kedua, banyak informasi yang harus disadap dan disebaarluaskan oleh setiap penyuluh kepada pihak-pihak di luar organisasi penyuluhan sehingga hubungan antar mereka juga perlu dikembangkan sebaik-baiknya. Ketiga, kegiatan penyuluhan memiliki peran yang beragam sesuai dengan aras birokrasi pemerintahan, sehingga kegiatan penyuluhan juga perlu diorganisasikan sebaik-baiknya untuk memperoleh dukungan dan mampu menggerakkan peran serta pimpinan di setiap tingkatan birokrasi pemerintahan.

Keempat, setiap penyuluh harus memiliki mobilitas tinggi untuk dapat melakukan kontak-kontak pribadi dengan banyak pihak. Oleh karena itu, diperlukan adanya pengorganisasian yang memungkinkan setiap penyuluh memiliki mobilitas tinggi. Kelima, setiap penyuluh harus memiliki hubungan timbal balik yang erat, baik dengan para peneliti (atau sumber informasi lainnya) maupun dengan masyarakat sasarannya terutama dalam menyampaikan umpan balik yang diberikan oleh para petani kepada para peneliti. Untuk keperluan seperti ini, sangat diperlukan pengorganisasian tertentu yang efektif. Keenam, penyuluhan pertanian, memerlukan hubungan yang akrab dengan semua sektor kegiatan yang dilaksanakaan dalam pembangunan pertanian sehingga diperlukan keberadaan pengorganisasian yang efektif dalam kegiatan penyuluhan pertanian dan kaitannya dengan sektor kegiatan lain. Ketujuh, efektivitas penyuluhan sangat ditentukan oleh kejelasan informasi yang disampaikan oleh penyuluhnya. Karena itu, kredibilitas penyuluh sebagai sumber informasi yang dapat dipercaya sangat dibutuhkan. Kondisi tersebut hanya dimungkinkan jika terdapat organisasi penyuluhan yang memberikan kejelasan tugas dan tanggung jawab kepada setiap penyuluhnya.

Beberapa isu pengorganisasian penyuluhan pertanian pada kegiatan penyuluhan pertanian di Kabupaten Pesawaran termasuk peran Pemerintah Daerah Kabupaten Pesawaran dalam aspek kelembagaan mencakup: 
1. Dalam kelembagaan BP4K Kabupaten Pesawaran, meskipun seharusnya sudah ada keterpaduan, namun masih ada pemisahan antara sektor perkebunan, perikanan, kehutanan, dan tanaman pangan sehingga pola koordinasi belum berjalan baik.

2. BP4K Kabupaten Pesawaran belum optimal dalam memberikan dukungan regulasi (keputusan bupati), dukungan anggaran maupun dukungan instrumeninstrumen yang dibutuhkan oleh BP3K dalam pelaksanaan penyuluhan maupun penilaian kelompok tani dan/atau gabungan kelompok tani.

3. Kelompok tani di tingkat desa idealnya tidak terpecah-pecah ke dalam sektor tertentu (kehutanan misalnya) karena idealnya sektorsektor tersebut adalah seksi atau bagian atau sub-bidang dari kelompok tani. Hal ini sangat terasa permasalahannya apabila dikaitkan dengan adanya bantuan dari Pemerintah Pusat atau kementerian tertentu atau bahkan OPD di lingkup Pemerintah Provinsi maupun Kabupaten Pesawaran yang justru berimplikasi terhadap pengkotakkotakan kelompok tani.

4. Penyebaran dan kompetensi tenaga penyuluh pertanian masih bias kepada sektor pertanian dan sub sektor pangan, khususnya padi. Kondisi ini menyebabkan terbatasnya pelayanan penyuluhan pertanian kepada petani yang mengusahakan komoditas non pangan maupun non pertanian yaitu perikanan dan kehutanan.

5. Terjadi alih tugas fungsional dari penyuluh pertanian pada posisi atau jabatan lain yang sering tidak memiliki relevansi dengan kompetensi dari penyuluh pertanian yang dialihfungsikan. Kondisi ini menyebabkan berkurangnya tenaga penyuluh pertanian di Kabupaten Pesawaran yang berakibat pada jumlah tenaga penyuluh pertanian yang tidak sebanding rasionya dengan jumlah petani/ kelompok tani yang harus dilayani.

6. Pengukuhan kembali penyuluh pertanian sebagai pejabat fungsional belum dilakukan sehingga penyuluh pertanian belum diakui eksistensinya sehingga tunjangan fungsionalnya belum dianggarkan oleh Pemerintah Kabupaten Pesawaran. Kondisi ini menyebabkan berkurangnya motivasi penyuluh pertanian untuk bekerja lebih baik.

7. Proses kenaikan pangkat masih sering terjadi keterlambatan yang berakibat pada pola karir yang tidak jelas. Kondisi ini berimplikasi pada kurangnya motivasi, etos kerja, serta kinerja para penyuluh pertanian untuk bekerja lebih baik.

8. Rekruitmen dan pembinaan karier penyuluh pertanian belum sepenuhnya berpedoman pada SK MenPAN No.19 Tahun 1999 dan ketentuan usia pensiun bagi penyuluh pertanian belum sepenuhnya dilaksanakan sesuai peraturan yang berlaku.

9. Peningkatan kompetensi penyuluh pertanian, terutama melalui Diklat, sudah jarang dilakukan. Hal ini menyebabkan rendahnya kemampuan dan kinerja penyuluh pertanian dalam menjalankan tugasnya dan menurunnya kredibilitas mereka di mata petani.

10. Tingkat usia penyuluh pertanian mayoritas berumur di atas 50 
tahun. Kondisi ini menyebabkan 10 tahun yang akan datang jumlah penyuluh pertanian menjadi sangat berkurang karena memasuki usia pensiun. Usia mendekati pensiun dalam beberapa penelitian akan sangat berpengaruh terhadap menurunnya kinerja (Suhanda, dkk, 2008).

11. Penyuluh Pertanian Swakarsa dan Swasta belum berkembang dengan baik, karena pembinaannya belum terprogram dan belum didukung oleh peraturan perundangundangan. Kondisi ini menyebabkan belum optimalnya peranserta petani dan swasta dalam penyelenggaraan penyuluhan pertanian.

12. Biaya operasional untuk penyuluh pertanian belum disediakan oleh Pemerintah Kabupaten Pesawaran. Hal ini menyebabkan frekuensi dan intensitas kunjungan penyuluh pertanian ke petani sangat kurang.

13. Fungsi penyuluhan yang kabur, karena penyuluh terlalu banyak melakukan kegiatan administrasi dan tugas-tugas lain di luar kegiatan menyuluh.

14. Luasnya wilayah kerja, besarnya jumlah keluarga petani yang menjadi sasarannya, serta kurangnya sarana mobilitas.

15. Lemahnya jalinan hubungan antara penyuluh dan peneliti.

16. Masih adanya duplikasi kegiatan dan pemborosan dana yang sebenarnya sangat terbatas.

Selain itu, permasalahan yang dihadapi dalam penyediaan dan pemanfaatan kelembagaan penyuluhan pertanian di Kabupaten Pesawaran adalah sebagai berikut:

(1) Masih sulitnya mendapatkan informasi dan teknologi yang sesuai dengan kebutuhan spesifik lokal pada wilayah binaan BP3K karena terbatasnya kemampuan penyuluh pertanian dan sarana prasarana yang dimiliki kantor BP3K untuk mengakses sumbersumber informasi dan teknologi. Kondisi ini menyebabkan kurang berkembangnya pengetahuan, kemampuan dan wawasan penyuluh pertanian untuk menyediakan materi penyuluhan yang dibutuhkan petani.

(2) Terbatasnya sarana dan prasarana yang dimiliki BP3K dalam melaksanakan tugas dan fungsinya. Kondisi ini menyebabkan rendahnya mobilitas penyuluh pertanian dan kurang optimalnya pelayanan terhadap petani.

(3) Pembiayaan penyuluhan pertanian yang bersumber dari Pemerintah, Provinsi dan Kabupaten baik melalui dana dekonsentrasi, dana alokasi umum (DAU), dan APBD maupun kontribusi dari petani dan swasta masih sangat terbatas. Kondisi ini menyebabkan penyelenggaraan penyuluhan pertanian tidak optimal, yang pada gilirannya menghambat pelaksanaan program pembangunan pertanian.

(4) Koordinasi penyelenggaraan penyuluhan pertanian kurang berjalan dengan baik serta kurangnya koordinasi dalam penyelenggaraan penyuluhan di semua tingkatan.

(5) Kelembagaan Penyuluhan Desa/Pos Penyuluhan Desa di semua desa belum terbentuk sesuai dengan ketentuan yang ada.

(6) Tata Hubungan Kerja penyelenggaraan penyuluhan pertanian, perikanan dan kehutanan di berbagai tingkatan belum tertata dengan baik, sehingga penyelenggaraan 
penyuluhan belum terintegrasi dan sinergis dengan baik.

(7) Keberadaan

Poktan/Gapoktan/KTNA maupun Kelompok Tani/Masyarakat Kehutanan, belum berfungsi secara efektif.

\section{Rekomendasi Kebijakan Penguatan Kelembagaan Penyuluh}

Berdasarkan isu kebijakan kelembagaan penyuluh pertanian serta analisis terhadap upaya yang dilakukan oleh Pemerintah Daerah Kabupaten Pesawaran sebagaimana tersebut di atas, maka hal-hal yang direkomendasikan dalam merancang suatu kelembagaan penyuluhan yang efektif, sedikitnya perlu diperhatikan tiga hal yang meliputi:

(1) Kelembagaan penyuluh pada tingkat kabupaten maupun kecamatan harus terus ditingkatkan kapasitasnya melalui skema capacity building yang komprehensif dan berkelanjutan.

(2) Kelembagaan penyuluh yang menggunakan penyuluh-penyuluh yang juga harus melaksanakaan tugas-tugas administrasi dan "pengaturan" akan menghancurkan kredibilitas penyuluhan yang merupakan organisasi pendidikan. Karena itu, tugas penyuluhan harus dipisahkan dengan tugas-tugas pengaturan.

(3) Kegiataan penyuluhan membutuhkan penyuluh yang andal dengan mobilitas tinggi. Karena itu, setiap penyuluh harus dilengkapi dengan tersedianya dana yang cukup untuk dapat merancang dan melaksanakan kegiatan-kegiatan penyuluhan yang seringkali banyak memerlukan sumberdaya (bahan, perlengkapan, tenaga kerja, dan waktu).

(4) Wilayah kerja penyuluhan (pertanian), pada umumnya tidak cukup memiliki pelayanan sosial yang memadai. Karena itu, seringkali sulit untuk mengangkat penyuluh-penyuluh yang andal yang mau ditugaskan di wilayah yang sulit untuk jangka waktu yang lama. Konsekuensinya adalah, kita akan berhadapan dengan sejumlah besar penyuluh dengan kualifikasi rendah, atau menggunakan sedikit penyuluh yang andal. Dalam keadaan seperti ini, pengorganisasian penyuluhan harus dirancang sedemikian rupa sehingga memungkinkan para penyuluh dapat dengan mudah dipindah tugaskan sesuai dengan kebutuhan setempat.

Sejalan dengan itu, organisasi penyuluhan pertanian memiliki sifat yang unik karena di satu pihak harus memiliki jalinan yang erat dengan organisasi pemerintahan yang memiliki kekuasaan sebagai pengambil keputusan dan penanggung-jawab kegiatan pembangunan (pertanian) di wilayah setempat; dan di lain pihak ia harus merupakaan organisasi pelayanan yang melaksanakan fungsi pendidikan yang sejauh mungkin dibebaskan dari segala macam bentuk pengaturan/pemaksaan. Oleh sebab itu, pengorganisasian penyuluhan pertanian harus diatur sedemikian rupa sehingga tetap memiliki hubungan "vertikal struktural" dengan organisasi pemerintahan, dan di lain pihak harus memiliki hubungan "horizontal fungsional" dengan lembaga-lembaga pendidikan, penelitian, organisasi-organisasi profesi dan dengan masyarakat sasarannya.

Di samping itu, dalam pengorganisasian penyuluhan pertanian harus selalu memperhatikan pentingnya 
keterlibatan masyarakat sasaran untuk berpartisipasi dalam kegiatan penyuluhan pertanian, sejak di dalam perumusan masalah, tujuan kegiatan, dan pengambil keputusan tentang perencanaan program penyuluhan, pelaksanaan kegiatan, pemantauan kegiatan, maupun evaluasi kegiatannya. Hal tersebut disebabkan karena hanya masyarakat petani yang tahu pasti tentang masalah yang dihadapi dan kegiatan yang perlu dilakukan sesuai dengan pandangan dan pola pikir mereka sendiri. Berikutnya, hanya petani sendiri yang mampu memberikan umpan balik yang terpercaya tentang sebab-sebab kelambanan adopsi inovasi yang ditawarkan oleh penyuluhnya serta petani sendirilah yang seharusnya menilai, apakah seorang penyuluh itu dinilai andal/tidak serta apakah program penyuluhan itu dinilai berhasil/tidak.

Secara teknis, beberapa rekomendasi yang dapat dilakukan dalam rangka peningkatan kapasitas kelembagaan BP3K di Kabupaten Pesawaran adalah :

a. Meskipun secara nasional, regulasi tentang tugas pokok dan fungsi kelembagaan sudah diatur, namun dalam rangka optimalisasi peran kelembagaan $\mathrm{BP} 3 \mathrm{~K}$ tersebut, maka perlu disusun Peraturan Bupati Pesawaran yang sekaligus mengatur Tugas Pokok, Fungsi serta Kewenangan antara BP4K, BP3K dan Posluhdes dalam satu hierarki sehingga ada kejelasan tugas, siapa mengerjakan apa dan siapa berbuat apa; karena di tingkat pusat aturan tentang tupoksi tersebut masih terpisah-pisah.

b. Memfungsikan BP3K yang telah ada dan membuat BP3K percontohan sebagai acuan bagi kecamatan lainnya dengan memberikan dukungan yang optimal.

c. Perlu disusunnya Standar Pelayan Minimal (SPM) dan Sistem Prosedur yang memuat pelayanan minimal kepada pelaku utama dan prosedur teknis pelaksanaan penyuluhan sehingga ada kejelasan tugas antara penyuluh $\mathrm{P} 2 \mathrm{~K}$ ataukah kewenangan institusi badan pelaksana.

d. Menyusun Peraturan Bupati tentang Tata Cara Peningkatan Kompetensi Penyuluh di Kabupaten Pesawaran

e. Pemberiaan Apresiasi dan Penghargaan Kepada BP3K dan Posluhdes serta Kelompok Tani yang berprestasi.

f. Perlu disusunnya Standarisasi dan evaluasi Kelompok Tani, Gapoktan dan KTNA dengan merujuk pada pedoman yang telah ada.

g. Meningkatkan koordinasi di semua tingkatan.

h. Melakukan penyebaran informasi kepada pelaku utama sektor pertanian maupun pelaku usaha pertanian melalui media massa dan media informasi lainnya.

\section{SIMPULAN}

Sektor pertanian, perikanan dan kehutanan sebagai sektor penting dalam struktur perekonomian Kabupaten Pesawaran memerlukan kelembagaan penyuluh serta sumber daya manusia (penyuluh) yang berkualitas dan berdaya saing. Dalam upaya mewujudkan sektor pertanian menjadi tulang punggung perekonomian masyarakat di Kabupaten Pesawaran dibutuhkan penyelenggaraan penyuluhan pertanian dengan dukungan kualitas penyuluh dan kualitas lembaga penyuluhan sebagai dua subsistem utama di antara tiga subsistem lain 
dalam sebuah sistem penyuluhan pertanian, perikanan dan kehutanan yang terpadu.

Meskipun kegiatan penyuluhan

di Kabupaten Pesawaran telah diselenggarakan oleh kelembagaan yang otonom (BP4K di tingkat kabupaten dan BP3K di tingkat kecamatan) namun secara faktual masih dilakukan dengan ketenagaan, mekanisme kerja, pembiayaan, sarana prasarana, serta metode penyuluhan yang tidak memenuhi standar. Dalam kelembagaan BP4K, adanya keharusan keterpaduan pengelolaan pada ragam subsektor namun ternyata terdapat pemisahan antara sektor perkebunan, perikanan, kehutanan, dan tanaman pangan sehingga pola koordinasi belum berjalan dengan baik meskipun berada dalam satu kelembagaan penyuluh.

Isu strategis yang sering muncul dalam pelayanan kelembagaan penbyuluh adalah bahwa BP4K Kabupaten Pesawaran belum optimal dalam memberikan dukungan regulasi (keputusan bupati), dukungan anggaran maupun dukungan instrumen yang dibutuhkan oleh BP3K dalam pelaksanaan penyuluhan maupun penilaian kelompok tani dan/atau gabungan kelompok tani. Pada saat yang sama, kelembagaan petani di tingkat desa juga masih terpecah-pecah ke dalam sektor tertentu padahal idealnya sektor tersebut adalah seksi atau bagian atau sub-bidang dari kelompok tani. Hal tersebut sangat terasa permasalahannya apabila dikaitkan dengan adanya bantuan dari pemerintah yang justru berdampak pada pengkotak-kotakan kelompok tani.

Oleh karena itu, pada penguatan aspek kelembagaan $\mathrm{BP} 3 \mathrm{~K}$ arahan rekomendasi peningkatan kapasitas dapat dilakukan seluruhnya dengan mengikuti model pelaksanaan programa dalam dimensi perencanaan, pengorganisasi dan pelaksanaan dari tiga sumber, yaitu sumber normatif, sumber regulatif, dan sumber partisipatif. Pada aspek normatif, berbagai fasilitasi harus secara konsisten dijalankan dengan menjalin kerja sama secara internal maupun eksternal. Secara internal kewenangan BP3K akan menjadi jelas dalam struktur kelembagaan penyuluh dan peran penyuluh sebagai salah satu profesi pemberdaya masyarakat dapat sinergi dengan profesi-profesi lain yang selama ini telah menunjukkan fungsi dan perannya dalam masyarakat. Pada aspek regulatiif, karena aspek kelembagaan penyuluh hanya merupakan salah satu dari sub sistem revitalisasi penyuluhan secara makro, maka Pemerintah Kabupaten Pesawaran harus juga berkomitmen dan sekaligus mendesain arahan skenario untuk pengembangan sub sistem lainnya dalam bentuk Rencana Terpadu Revitalisasi Penyuluhan Pertanian, Perikanan dan Kehutanan sehingga ientagrasi dan koordinasi antar sektor dalam pembangunan dan antar subsistem dalam sistem penyuluhan dapat berjalan dengan baik dan maksimal. Adapun pada aspek partisipatif, dalam pengorganisasian penyuluhan pertanian harus memberikan kewenangan yang lebih besar kepada masyarakat (lapisan bawah) untuk mengambil keputusan tentang perencanaan program, pelaksanaan, maupun evaluasi secara mandiri.

\section{DAFTAR PUSTAKA}

Clear, J.B \& R.P. Bentz. (1987). Organization Design and Extension Administration. In B.E. Swanson, Agricultural Extension. A Reference Manual. p. $161-183$

Dunn, W.N. (2000). Pengantar Analisis Kebijakan Publik 
(terjemahan Samodra Wibawa, dkk). Yogyakarta : Gadjah Mada University Press.

Hogwood, B. W. \& Gunn, L. A. (1984). Policy Analysis For The Real World. London: Oxford University Press.

Laporan Tahunan Kementerian Pertanian Republik Indonesia Tahun 2015.

Majchrzak, A. (1981). Method For

Policy Research. Sage

Publication. London: Beverly

Hills.

Rencana Strategis Badan Pelaksana

Penyuluhan Pertanian,

Perikanan, dan Kehutanan

Kabupaten Pesawaran Tahun 2015-2020.

Soeprapto, H. R. R. (2003). Pengembangan Kapasitas Pemerintah Daerah Menuju Good Government. Pidato Pengukuhan Guru Besar dalam Ilmu Administrasi Pembangunan pada Fakultas Ilmu Administrasi Universitas Brawijaya: Malang.

Suhanda, N. S. (2008). Job Performance Of Agricultural Extension Agent In West Java Province. Jurnal Penyuluhan, 4 (2), p. 100-108.

Sunartomo, A. Fajar. (2016). Kapasitas Penyuluh Pertanian Dalam Upaya Meningkatkan Produktivitas Pertanian Di Jawa Timur. Agroekonomika (Jurnal Sosial Ekonomi dan Kebijakan Pertanian), 5(2). p. 125-137.

Vintarno, J., Sugandi, Suprayogi, Y. \& Adiwisastra, J. (2019). Perkembangan Penyuluhan Pertanian Dalam Mendukung Pertumbuhan Pertanian Di Indonesia. Jurnal Responsive, 1(3). p. $90-96$.
Wahab, S. A. (2002). Analisis Kebijakan dari Formulasi ke Implementasi. Kebijakan Negara. Jakarta: Bumi Aksara.

Wahyuni, S., Helmi, Tanjung, H. B, Oktavia, Y. (2019). Role Of Agricultural Extension Center (BPP) in Extention of Food Commodities (Case Study In Tanah Datar District). Jurnal AGRISEP, 18(2). p. 235 - 248.

Wicaksono, K. W. (2012). Problematika Dan Tantangan Desentralisasi Di Indonesia. Jurnal Bina Praja, 4(1).p. $21-28$.

Undang Undang No. 16 Tahun 2006 tentang Sistem Penyuluhan Pertanian, Perikanan dan Kehutanan 